\title{
Effects of Partially Purified Preparations with Nonsuppressible Insulin-Like Activity (NSILA-S) on Sulfate Incorporation into Rat and Chicken Cartilage
}

\author{
A.E. Zingg and E.R. Froesch* \\ Metabolic Unit, Department of Medicine, University of Zürich, Switzerland \\ Received: April 2, 1973, and in revised form: July 13, 1973
}

Summary. Several partially purified preparations of NSILA-S were tested for sulfation activity on rat and chicken embryo cartilage. A clearcut stimulation was obtained with as little as $0.1 \mu \mathrm{U} / \mathrm{ml}$ and a near maximal effect with $10 \mu \mathrm{U} / \mathrm{ml}$. In no instance could sulfation activity be dissociated from NSILA-S. It is, therefore, likely that NSILA-S and sulfation activity are exerted by one and the same molecule. It is, however, compatible with our results and those from other laboratories that still other substances with sulfation activity besides
NSILA-S may be present in serum. Morell's findings $[7,8]$ according to which NSILA-S stimulates growth and metabolism of chicken embryo fibroblasts and our results on NSILA-S stimulation of sulfate incorporation into cartilage point to a possible physiological role of NSILA-S as a growth factor.

Key words: Nonsuppressible insulin-like activity, sulfation factor, somatomedin, growth factor, insulin, cartilage, acromegaly.
In 1959 several groups of investigators observed that only a small portion of total insulin-like activity of serum was inhibited by guinea pig anti-insulin serum. This activity of serum was termed nonsuppressible insulin-like activity (NSILA) [1]. Later it was shown that NSILA consists of at least 2 components [2]. 1) NSILA-P (precipitated by acid-ethanol), amounting to approximately $80 \%$ of total NSILA, with a molecular weight of approximately 100000 and 2) NSILA-S (soluble in acid-ethanol), amounting to approximately $20 \%$ of total NSILA, with a molecular weight of 7500 . NSILA-S is a small, one chain peptide with 2 or 3 disulfide bridges. Humbel et al. [3] have purified this molecule from serum and have determined its aminoacid composition which shows no similarity to that of insulin or proinsulin. NSILA-S and crystalline insulin are very similar with regard. to their qualitative effects on adipose tissue and muscle in vitro. NSILA-S is approximately 50 times less active, mole per mole, than insulin [4]. Lately, several clearcut differences have been observed between these two substances. First, NSILA-S is barely inactivated by the perfused rat liver [4]. Second, NSILA-S has a prolonged blood sugar lowering activity after i.v. administration in adrenalectomized rats and stimulates glucose incorporation into glycogen of muscle of diabetic rats for much longer than insulin $[4,5,6]$. Third and most importantly, NSILA-S is approximately 20 times more active than insulin in stimulating thymidine incorporation into DNA and cell replication of fibroblasts in culture [7, 8]. Because of this growth promoting effect of NSILA-S on undifferentiated cells we were interested to investigate the influence of NSILA-S on more differentiated cells. The studies were also motivated by the finding that partially purified preparations of sulfation factor

* This work was supported by a grant (3.85.69) from the Schweizerische Nationalfonds. exerted nonsuppressible insulin-like activity $[9,10]$. The so called sulfaction factor of serum stimulates sulfate incorporation into chondroitin sulfate of cartilage and thymidine incorporation into DNA [11]. Therefore, the sulfation assay was set up to find out whether or not NSILA-S has any activity and if so, whether the sulfation factor might indeed be the same substance as NSILA-S, as proposed earlier $[9,10]$. Furthermore, the effects of NSILA-S were compared with those of insulin, which has been demonstrated to be a "sulfation factor" in pharmacological concentrations [12].

\section{Material and Methods}

Sulfate incorporation into cartilage of rats was assayed by the technique of Yde [13]. Instead of hypophysectomized animals we used female OsborneMendel rats after three days of fasting, with an initial weight of $60 \mathrm{~g}$. They had free access to water containing vitamin $K$ in order to prevent bleeding. Weight loss after 3 days of fasting averaged $30 \%$. The two lowest ribs were used [13]. Segments of cartilage were prepared from the middle portion of the ribs, at least $2 \mathrm{~mm}$ removed from the costochondral junction and $5 \mathrm{~mm}$ from the sternum. The ribs were cut into pieces of $2 \mathrm{~mm}$ length (dry weight between 0.4 and $0.8 \mathrm{mg}$ ). In this manner 14 segments of cartilage were obtained per rat. Krebs phosphate buffer was used as an incubation medium [14]. To each $100 \mathrm{ml}$ of medium was added $1 \mathrm{mg}$ of phenol red as $\mathrm{pH}$-indicator and $200 \mathrm{mg}$ of human serum albumin, the latter to keep insulin and NSILA-S in solution and to prevent their adsorption to glass.

The day before the experiment the active growth promoting substances were added to the medium, pipetted into the vials and kept frozen. The following 
morning 4 rats were decapitated, the ribs were dissected on a sterile workbench, the segments prepared and immediately added to the medium. Segments from the same animal were distributed at random among the samples to be assayed. The incubation was carried out in a Dubnoff shaking incubator at $37^{\circ} \mathrm{C}$ and 60 r.p.m. After $6 \mathrm{~h}$ of preincubation, $100 \mu \mathrm{l}$ of medium containing $1 \mu \mathrm{Ci}$ of ${ }^{35} \mathrm{~S}$ was added. $24 \mathrm{~h}$ later, cultures of the incubation medium were made to detect eventual bacterial contamination, the $\mathrm{pH}$ was determined and the vials were put in boiling water for $5 \mathrm{~min}$ to terminate the reaction. Each segment was put into a hole of an agglutination plate, the plate covered with gauze and put under running tap water for $12 \mathrm{~h}$. The segments were air-dried for $20 \mathrm{~h}$, weighed on a microbalance, with an accuracy of $\pm 5 \mathrm{ug}$, put in scintillation vials with $90 \%$ formic acid and boiled in a water bath for $40 \mathrm{~min}$ with constant shaking. $5 \mathrm{ml}$ of a scintillation cocktail (Instagel) was added and ${ }^{35} \mathrm{~S}$ was counted. The results were expressed in cpm $/ \mathrm{mg}$ dry weight of cartilage. In a few instances cartilage from chicken embryos was used according to the technique of Hall [15]. The conditions were the same as those chosen for rat cartilage except for a preincubation time of $2 \mathrm{~h}$ and an incubation time of $6 \mathrm{~h}$.

Three different preparations of NSILA.S were obtained from Dr. R.E. Humbel (Institute of Biochemistry, University of Zurich). The large scale purification procedure of NSILA-S starts with an acetone powder of Cohn fraction $B$ of human plasma, subsequent acid alcohol extraction and purification on Sephadex G-75 in $1 \mathrm{M}$ acetic acid, according to methods previously described $[3,6]$. Serum of a healthy 24 year old man and of 2 patients with active acromegaly were used as standard sera. For statistical analysis Student's T-test was applied. The specific activity of the NSILA-S preparations was determined in the rat epididymal adipose tissue assay standardized with crystalline pork insulin [1].

\section{Results}

As may be seen from Fig. 1, three preparations of NSILA-S with specific activities from 0.8 to 61.0 $\mathrm{mU} / \mathrm{mg}$ stimulate the incorporation of ${ }^{35} \mathrm{~S}$ into rat cartilage. In the steep ascending part of the curve, between 0.1 and $10 \mu \mathrm{U} / \mathrm{ml}$, all three curves are similar although by no means parallel. Almost maximal effects are obtained with as little as $10 \mu \mathrm{U}$ of NSILA$\mathrm{S} / \mathrm{ml}$. The preparation with the lowest specific activity $(0.8 \mathrm{mU} / \mathrm{mg})$ is inhibitory at higher concentrations. Fig. 2 A shows that the effects of maximal concentrations of insulin and NSILA-S on ${ }^{35}$ S-incorporation into rat cartilage are similar. However, NSILA-S is active in the microunit range, insulin only in the milliunit range. It appears from these curves that NSILA-S is 100 to 1000 times more active than in- sulin compared to the respective activities on adipose tissue.

As shown in Fig. 2 B, $10 \%$ serum of an acromegalic patient stimulates ${ }^{35}$-S-incorporation to a maximum of $250 \%$ above base line. This value is not quite significantly higher than that obtained with $500 \mu \mathrm{U}$ of NSILA-S $/ \mathrm{ml}(0.10>p>0.05)$ and significantly higher $(0.02>p>0.01)$ than that obtained with $10 \mu \mathrm{U} / \mathrm{ml}$ of NSILA-S. However, the curve obtained with serum has another shape and is steeper than that with NSILA-S or insulin. 10\% serum of a normal subject stimulates ${ }^{35} \mathrm{~S}$ incorporation to $179 \%$ above base line which is equivalent to the effect of approximately $2 \mu \mathrm{U} / \mathrm{ml}$ of NSILA-S. These data are in good agreement with the finding of Jakob et al. [2] that $1 \mathrm{ml}$ of serum contains approximately 10 to $20 \mu \mathrm{U}$ of NSILA-S. Since the slope of ${ }^{35} \mathrm{~S}$-incorporation into rat cartilage varies considerably from day to day, the results of a direct comparison between serum dilutions and NSILA-S dilutions are presented in Fig. 3. The differences between the effects of serum and of purified NSILA-S are evident. Again, maximal stimulation by $10 \%$ serum of an acromegalic patient

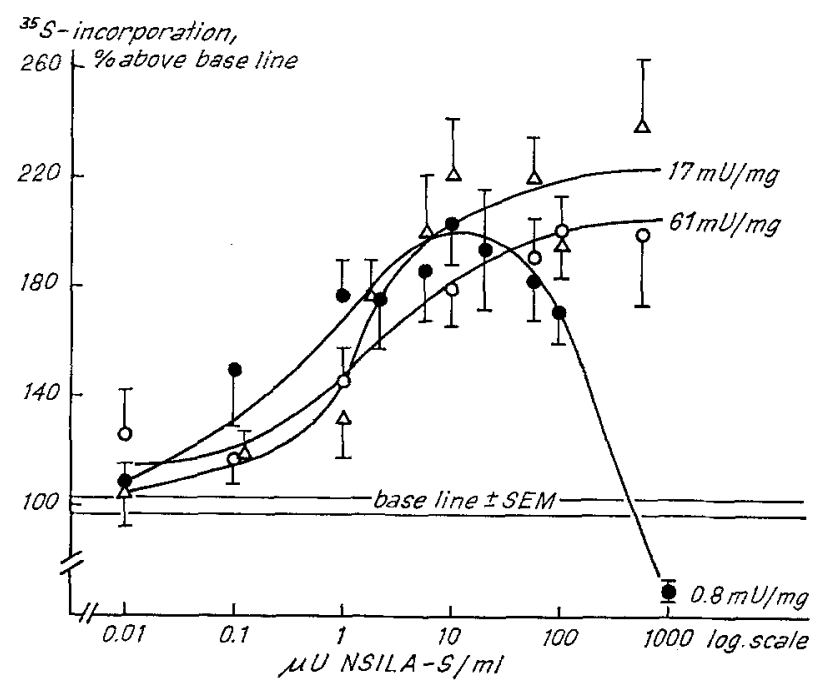

Fig. 1. Effects of three different preparations of NSILA-S on ${ }^{35}$ S-incorporation into fasted rat costal cartilage in vitro. Each point gives the mean value of at least 8 flasks (lower doses). Crossbars indicate the SEM

was significantly greater than by $50 \mu \mathrm{U}$ of NSILA-S $/ \mathrm{ml}$. The slope was much steeper in the case of serum and a significant stimulation was no longer observed at a serum concentration of $0.12 \%$. Although $50 \mu \mathrm{U}$ of NSILA-S $/ \mathrm{ml}$ stimulated ${ }^{35} \mathrm{~S}$-incorporation into cartilage to a lesser extent than $10 \%$ serum, the stimulation remained almost constant at concentrations between 5.45 and $0.62 \mu \mathrm{U} / \mathrm{ml}$. Very low concentrations of NSILA-S still stimulated ${ }^{35}$ S-incorporation into rat cartilage and the slope of the dose response curve in the low concentration range was very flat, supporting 
the results presented in Fig. $2 \mathrm{~A}$. The results presented in Table 1 show that NSILA-S also stimulates cartilage of chicken embryos. Crystalline insulin in a concentration of $100 \mathrm{mU} / \mathrm{ml}$ and $10 \%$ serum of a patient with acromegaly have a somewhat greater effect in this assay system than $5 \mu \mathrm{U}$ of NSILA-S $/ \mathrm{ml}$. dose-response curve obtained with acromegalic serum was much steeper than that obtained with NSILA-S or insulin. High, pharmacological doses of insulin were required to simulate the effects of apparently "physiologic" doses of NSILA-S. There can be no doubt, however, that the effects of serum and of
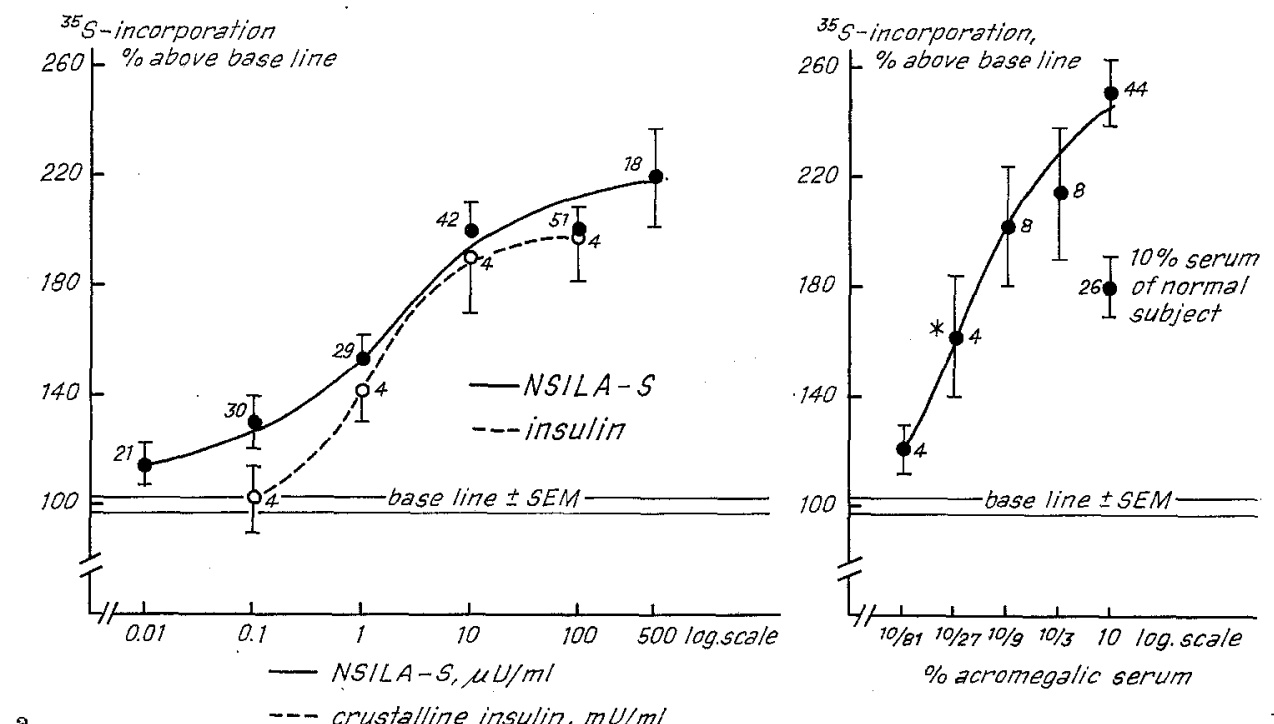

b

Fig. 2a. Dose-response curves of the in vitro sulfate incorporation into fasted rat costal cartilage stimulated by crystalline insulin $(\mathrm{mU} / \mathrm{ml})$ and by NSILA-S $(\mu \mathrm{U} / \mathrm{ml})$. All values obtained with three different preparations of NSILA-S were pooled. Same scales as in $2 \mathrm{~B}$ )

Fig. 2b. Dose-reponse curve of the in vitro sulfate incorporation into fasted rat costal cartilage stimulated by serum of a patient with active acromegaly and of a normal subject. Crossbars indicate the SEM. $\mathbf{n}=$ number of segments. * $p<0.005$ against basal incorporation. Same scales as in 2 A)

Table 1. Sulfate incorporation into chicken embryo cartilage stimulated by NSILA-S., insulin and serum of an acromegalic patient. Values are given in \% of basal incorporation. Crossbars indicate the SEM. $n=$ number of segments. ${ }^{*} p<0.001$ against basal incorporation.

Incorporation of ${ }^{35} \mathrm{~S}$ into chicken embryo cartilage in \% above basal incorporation under stimulation with

\begin{tabular}{|c|c|c|c|}
\hline Basal & $\begin{array}{l}\text { NSILA-S, } 5 \mu \mathrm{U} / \mathrm{ml} \\
(0.8 \mathrm{mU} / \mathrm{mg} \mathrm{dry} \text { weight })\end{array}$ & $\begin{array}{l}\text { Crystalline insulin } \\
100 \mathrm{mU} / \mathrm{ml}\end{array}$ & $\begin{array}{l}10 \% \text { serum of patient } \\
\text { with acromegaly }\end{array}$ \\
\hline $\begin{array}{l}100 \% \pm 3.2 \% \\
(n=27)\end{array}$ & $\begin{array}{l}168 \% \\
(n=8)\end{array} \pm 15.2 \%$ & $\begin{array}{l}192 \%{ }_{(n)}^{*} \pm 11.8 \% \\
\end{array}$ & $\begin{array}{l}179 \% * \\
(n=4)\end{array} \pm 9.8 \%$ \\
\hline
\end{tabular}

\section{Discussion}

The sulfation assay with rat cartilage is time consuming and relatively inaccurate. We preferred this assay to the chicken assay because maximal stimulation is greater. Our main findings may be expressed in the following manner: NSILA-S purified on a large scale from human serum stimulates the incorporation of ${ }^{35} \mathrm{~S}$ into both rat and chicken cartilage. Stimulation of rat and chicken cartilage occurs at concentrations of purified NSILA-S in which this peptide seems to be present in serum under physiological conditions. $10 \%$ serum of an acromegalic patient was slightly more active than maximal concentrations of purified NSILA-S in the rat cartilage assay, but not in the chicken assay. The ascending part of the purified NSILA-S on rat cartilage are different since the dose response curves are not the same. We have no explanation why ${ }^{35} \mathrm{~S}$-incorporation tended to show a plateau at $50 \%$ above the baseline at concentrations of NSILA-S between 0.01 and $1 \mu \mathrm{U} / \mathrm{ml}$.

Our results support Hall's suggestion [9] that NSILA-S and the sulfation factor may be biological activities of one and the same molecule in serum. Since the incorporation of ${ }^{35} \mathrm{~S}$ into cartilage was stimulated to a greater extent by maximal concentrations of acromegalic serum than by maximal concentrations of NSILA-S and since the dose response curves have entirely different slopes, it is likely that still other substances in serum have sulfation activity or else that NSILA-S is altered during the extraction procedure. 
The following two major findings support the hypothesis that NSILA-S and one of the principle molecules with sulfation activity are probably identical. First, Hall [9] used almost the same purification procedure as was used by our group [3,6] to purify NSILA-S. The physicochemical similarities between the sulfation factor and NSILA-S are further stressed in a recent publication of Uthne [16]. The ratio of

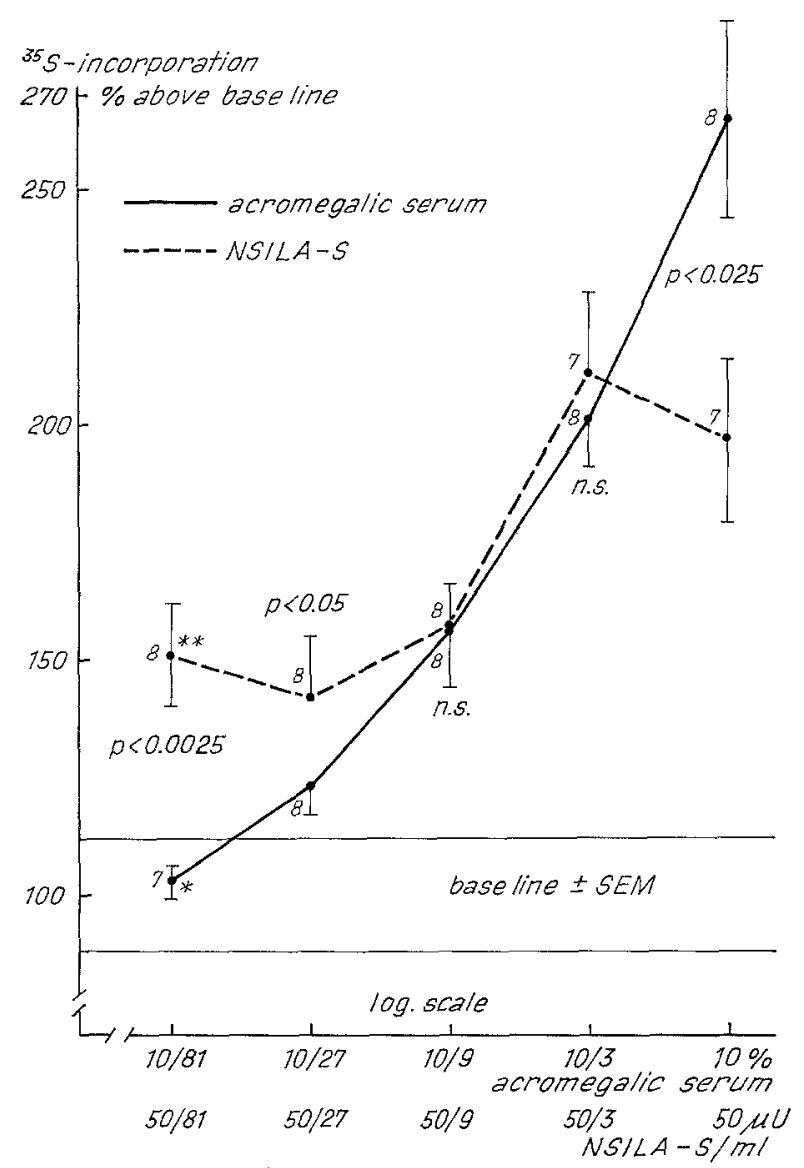

Fig. 3. ${ }^{35} \mathrm{~S}$-incorporation into fasted rat cartilage in the same experiment under the influence of serum of an acromegalic patient and of NSILA-S $(61 \mathrm{mU} / \mathrm{mg})$, each in 5 concentrations. Each point gives the mean of the results of 8 flasks and the brackets indicate the SEM

NSILA to sulfation activity remained similar during a 6500 -fold purification of sulfation activity and the thymidine factor could not be removed by this preparative procedure $[9,10]$. Second, the ratio of NSILA-S to sulfation activity was similar in 3 preparations of NSILA-S with $0.8,17$ and $61 \mathrm{mU} / \mathrm{mg}$, respectively.

Partially purified preparations of sulfation factor and serum of acromegalic patients have been shown to exert the following effects, common to insulin and, in part, also to NSILA-S. Serum fractions with sulfation activity stimulate amino acid incorporation into muscle and cartilage [17], leucine and sulfate in- corporation into proteinpolysaccharide complexes, uridine incorporation into RNA as well as thymidine incorporation into DNA of cartilage of hypophysectomized rats and of chicken embryo fibroblasts $[7,8$, $12,14,18,19]$. They also promote He-La cell growth [20]. Furthermore, they also exert an antilipolytic effect [21]. Because of its growth promoting effect, the sulfation factor has lately been baptized "Somatomedin" [22]. In recent experiments in our laboratories both activities were found in the same serum fractions. In these same fractions both activities were found to be decreased in pituitary dwarfs and increased in acromegalics (Schlumpf, in preparation).

There appears to be some disagreement as to the ratio of NSILA-S to sulfation activity. Hall $[9,10]$ claims that 1 sulfation unit defined as sulfation activity per $\mathrm{ml}$ of normal serum corresponds to about $200 \mu \mathrm{U}$ of NSILA. According to Jakob et al. [2] only $10-20 \%$ of total serum ILA $(200 \mu \mathrm{U} / \mathrm{ml})$ corresponds to NSILA-S.

Therefore, we would assume that 1 sulfation unit should be equivalent to approximately 10 to $20 \mu \mathrm{U}$ of NSILA-S. In fact, we have found that $10 \%$ serum of a normal subjects exerts approximately the same effect as $2 \mu \mathrm{U}$ of purified NSILA-S. However, in view of the different slopes obtained with serum on one hand and purified NSTLA-S on the other hand, quantitative estimates based on curves obtained with serum appear hardly justified. It is also interesting that Hall [9] found the same ratio of NSILA to sulfation activity before and after acid-alcohol extraction of serum, a procedure by which NSILA-P is removed. We have tested several partially purified preparations of NSILA-P in the sulfation assay (200 $\mu \mathrm{U} / \mathrm{mg}$ ) and have found them to be inactive in low and even inhibitory in higher concentrations. Our preparation of NSTLA-S with $0.8 \mathrm{mU} / \mathrm{mg}$ was also inhibitory at $1000 \mu \mathrm{U} / \mathrm{ml}$. Whether or not these inhibitory effects are due to artefacts produced during the purification procedure is unknown. However, these complications will make it difficult to accurately assess the quantitative relationship in serum and serum fractions between NSILA-S and sulfation factor. For this purpose, radioimmunoassays would be of great help. So far, we have been unsuccessful in immunizing guinea pigs and rabbits against NSILA-S and, as. far as we know, an immunoassay for sulfation factor does not yet exist.

Acknowledgements. We wish to thank Miss Monica Mäder for expert technical assistance and the staff of the Stoffwechsellabor for continued help and encouragement.

\section{References}

1. Froesch, E.R., Bürgi, H., Ramseier, E.B., Bally, P., Labhart, A.: Antibody-suppressible and nonsuppressible insulin-like activities in human serum and their physiologic significance. An insulin assay with adipose tissue of increased precision and specificity. J. elin. Invest. 42, 1816-1834 (1963) 
2. Jakob, A., Hauri, Ch., Froesch, E.R.: Nonsuppressible insulin-like activity in human serum. III. Differentiation of two distinct molecules with nonsuppressible ILA. J. clin. Invest. 47, 2678-2688 (1968)

3. Humbel, R.E., Bünzli, H., Mülly, K., Oelz, O., Froesch, E.R., Ritschard, W.J.: Insulin-like substances: the insulin dimer and nonsuppressible ILA. Proceedings of the VII Congress of the Internat. Diabetes Federation, Buenos Aires, Excerpta Medica International Congress Series No. 231, 306-317 (1970)

4. Oelz, O., Jakob, A., Froesch, E.R. : NSILA of human serum. V. Hypoglycaemia and preferential metabolic stimulation of muscle by NSILA-S. Europ. J. clin. Invest. 1, 48-53 (1970)

5. Froesch, E.R., Müller, W.A., Bürgi, H., Waldvogel, M., Labhart, A.: NSILA of human serum. II. Biological properties of plasma extracts with NSILA. Biochim. biophys. Acta (Amst.) 121, 360-374 (1966)

6. Oelz, O., Froesch, E.R., Bünzli, H. F., Humbel, R.E., Ritschard, W.J.: Antibody suppressible and nonsuppressible ILA. Handbook of Physiology, section 7; endocrinology, volume 1. endocrine pancreas, D.F. Steiner and N. Freinkel, eds. 685-702 (1970)

7. Morell, B., Froesch, E.R.: Fibroblasts as an experimental tool in metabolic and hormone studies. I. Growth and glucose metabolism of fibroblasts in culture. Europ. J. clin. Invest. 3, 112-118 (1973)

8. Morell, B., Froesch, E.R.: Fibroblasts as an experimental tool in metabolic and hormone studies. II. Effects of insulin and nonsuppressible insulin-like activity (NSILA-S) on fibroblasts in culture. Europ. J. clin. Invest. 3, 119-123 (1973)

9. Hall, K.: Human Somatomedin: Determination, occurrence, biologic activity and purification. Acta endocr. 70, Suppl. 163 (1972)

10. Hall, K., Uthne, K.: Human Growth Hormone and Sulfation Factor. In: Pecile A. and Mueller, E., Eds. Proc. Second. Int. Symp. Growth Hormone 192-198 (1972)

11. Van Wyk, J.J., Hall, K., Van den Brande, J.L., Weaver, R.P.: Further purification and characterisation of sulfation factor and thymidine factor from acromegalic plasma. J. clin. Endocr. 32, 389-403 (1971)

12. Salmon, W.D., DuVall, M.R., Thompson, E.Y. Stimulation by insulin in vitro of incorporation of ${ }^{35}$-S-sulfate and 14_C-leucine into protein-polysaccharide complexes, 3-H-thymidine into DNA and
3-H-uridine into RNA of costal cartilage from hypophysectomized rats. Endocrinology 82, 493-499 (1968)

13. Yde, H.: A simplified technique for the determination of $\mathrm{GH}$ dependent sulfation factor using intact animals. Acta endocr. 57, 557-564 (1968)

14. Daughaday, W.H., Reeder, C.: Synchronous activation of DNA synthesis in hypophysectomized rat cartilage by GH. J. Lab. clin. Med. 68, 357-370 (1966)

15. Hall, K.: Quantitative determination of the sulfation factor activity in human serum. Acta endocr. 63 $338-350(1970)$

16. Uthne, K.: Human somatomedins, purification and some studies on their biological actions. Acta endocr. 73, Suppl. $175(1973)$

17. Salmon, W.D., DuVall, M.R.: In vitro stimulation of leucine incorporation into muscle and cartilage protein by a serum fraction with sulfation factor activity: Differentiation of effects from those of GH and insulin. Endocrinology 87, 1168-1180 (1970)

18. Salmon; W.D., DuVall, M.R.: A serum fraction with sulfation factor activity stimulates in vitro incorporation of leucine and sulfate into protein polysaccharide complexes, uridine into RNA and thymidine into DNA of costal cartilage from hypophysectomized rats. Endocrinology 86, 721-727 (1970)

19. Raben, M.S., Murakawa, S., Matute, M. : Some observations concerning "Thymidine Factor". In: Pecile A. and Mueller, E., Eds. Proc. Second Int. Symp. Growth Hormone 124-131 (1972)

20. Salmon, W.D., Hosse, B.R.: Stimulation of He-La cell growth by a serum fraction with sulfation factor activity. Proc. Soc. exp. Biol. (N.Y.) 136, 805-808 (1971)

21. Underwood, L.E., Hintz, R.L., Voina, S.J., Van Wyk, J.J.: Somatomedin, the plasma sulfation factor, is antilipolytic. Clin. Res. 20, 74-79 (1972)

22. Daughaday, W.D., Hall, K., Raben, M, S. Salmon, W.D., Van den Brande, J.L., Van Wyk, J.J.: Somatomedin: Proposed designation for sulfation factor. Nature (London) 236, 107 (1972)

Prof. E.R. Froesch

Stoffwechsellabor, C-Lab. 47

Medizinische Klinik

Kantonsspital

CH-8006 Zürich

Schweiz 